\title{
An Empirical Study on Urban Tourist's Satisfaction of Chongqing
}

\author{
Li Zhiwei \\ Tourism and Service College, Chongqing University of Education \\ Chongqing, China \\ E-mail: 407209712 @qq.com
}

\begin{abstract}
As an important symbol of a city's internationalization and modernization, the development of urban tourism gives great impetus to the promotion of economy, culture, environment and sustainable development of a city ,thus it has received wide attention by major cities. Due to the widespread attention of everywhere, the urban tourism market competition goes increasing fiercely. In order to ensure sustained and rapid development of urban tourism, how to improve the urban tourism's satisfaction has become a major task for the destination management The paper, by using factor analysis, tries to find out the most important factor that influences urban tourist's satisfaction of Chongqing through the study of urban tourist's satisfaction. Results show Chongqing urban tourism got a lower score in transportation service, tour guide service, richness of information provided in sightseeing place, traffic convenience in and around city and tourist area capacity, the main measure to improve urban tourism satisfaction is to improve Chongqing urban tourism service. The development of urban tourism not only relies on the landscape and environment, service is more important.
\end{abstract}

Keywords-Chongqing; Urban tourism; tourist's satisfaction; factor analysis; suggestion

\section{INTRODUCTION}

As an important symbol of a city's internationalization and modernization, the development of urban tourism gives great impetus to the promotion of economy, culture, environment and sustainable development of a city, thus it has received wide attention by major cities. Chongqing urban tourism was developed after it became municipality. In over ten years development, it enjoys a good momentum now. In 2008, Forbes released The Most Suitable City for Developing Tourism in Mainland China, Chongqing, second to Xi' an and Guilin, got third place in the most suitable city for developing tourism in western China. In 2011, Chongqing received 222 million tourists from home and abroad, with year-on-year growth of $37.3 \%$.Tourism revenue in Chongqing totaled 126.862 billion, which has increased $38.22 \%$ from same period of last year.

Due to the widespread attention of everywhere, the urban tourism market competition goes increasing fiercely. In order to ensure sustained and rapid development of urban tourism, how to improve the urban tourism's satisfaction has become a major task for the destination management and marketing. Through the demonstrative study on the domestic tourist's satisfaction and impact factors, this paper finds out the significant factors that influence Chongqing urban tourism satisfaction, thus provided basis for the sustainable and healthy development of Chongqing urban tourism.

\section{RELATED RESEARCH PROGRESS}

In view of market management, the customer is the resource of corporate revenue, is the base of enterprises sustainable development, is the fundamental of enterprise survival. A study published in Harvard Business View pointed that the customer retention rate increased by $5 \%$, will make the company profits increased by $25 \%$ to $85 \%$.How to acquire new customers and retained existing ones has been the important guarantee of the enterprise' $\mathrm{s}$ existence and development. This was true of all industries but especially for the urban tourism development, only by constantly improve of urban tourism satisfaction, urban tourism can have vitality and competitiveness.

The current research field about tourist's satisfaction largely involved in scenic regions, hotel and travel destination. The research results mainly embody in the construction of evaluation system and empirical research. Dong and Yang (2005) extracted the main factors affecting tourist's satisfaction on tourism areas and used fuzzy comprehensive evaluation method (FCEM)to built the mathematical model evaluation system. Using the FCEM, Nan (2008) gave the quantitative evaluation to tourist's satisfaction on tourism areas. Guo and Zhang (2010) constructed the tourist's perception and satisfaction theory model and also made an empirical analysis on three tourism areas in Lanzhou, China. From the influencing factors of tourist's satisfaction on red tourism regions, Jiao (2012) established an index system to evaluate tourist's satisfaction on red tourism regions. Structural equation model is used by Huang (2006) to build the hotel customers satisfaction evaluation model and carried on empirical study. Using stratified sampling and systematic sampling methods, Huang and Chen (2010) obtained the influence factors of tourists' satisfaction on hotels of famous tourism areas. Based on the random sampling and a large number of questionnaires, Chen (2006) gained membership degrees of tourist's perception and satisfaction on Kai Feng. Chen also analyzed the tourist's satisfaction on Kaifeng tourism regions based on FCEM. $\mathrm{Li}$ (2008) took Xi'an domestic market as an example, put forward the methods to promote tourist's satisfaction on the base of constructing a destination tourist's satisfaction evaluation index system and the method of co-plot and multivariable regression analysis.

Based on the previous literatures, the author found that the study of tourist's satisfaction has been moved from qualitative research to quantitative research, however the 
related empirical study is less. This paper tries to find out the most important factor that influences urban tourist's satisfaction of Chongqing through the study of urban tourist's satisfaction and influence factors.

\section{METHOD}

\section{A. Confirmation of Evaluate Index}

Referred to the predecessors' achievements, this paper tries to measure the tourist's satisfaction from urban tourism landscape, catering, transportation, commodity, entertainments, service, environment, price and other aspects. In specific indexes, selected those significant factors that influence customers perception as the specific indexes, Thus, the tourist' $\mathrm{s}$ core issue of concern can be caught and the accuracy about tourists' answers also can be ensured. On tourism landscape, mainly investigated on tourist's satisfaction on landscape characteristics, landscape value and landscape richness. On catering, it mainly inspects tourist's satisfaction on food features and food quality. On transportation and entertainment, it mainly inspects tourist's satisfaction on traffic convenience degree, entertainment features and entertainment richness. On tourist shopping, it mainly inspects tourist's satisfaction on commodity with local characteristic and the richness of product types. On service, mainly inspected tourist' $s$ satisfaction on transportation service, hotel service, catering service, tour guide service and travel consultation. On price, it mainly inspects tourist's satisfaction on ticket and recreational activities' price, accommodation price and commodity price.

Therefore, the author chose 24 evaluation indexes, as shown in table1, and divided every evaluation index into following five levels: very dissatisfied 、 dissatisfied, general, satisfied and very satisfied and these levels corresponded respectively with $1,2,3,4,5$ points. This paper chose the tourists at Chongqing Ciqikou town, Three Gorges Museum, Hongyadong, Jiefangbei, Bai Mansion and Refuse Pit as samples, The sampling survey is made by using the non-probability sampling, that is, convenience sampling. The survey conducted from September 1 st to October 7 th 2012. A total of 300 questionnaires are distributed, among which 278 are valid.

TABLE I. EVALUATION INDEX

\begin{tabular}{|c|c|c|c|}
\hline Index & Evaluation Content & Index & Evaluation Content \\
\hline $\mathbf{X 1}$ & $\begin{array}{l}\text { Overall evaluation on } \\
\text { urban tourism } \\
\text { products }\end{array}$ & $\mathbf{X 1 3}$ & $\begin{array}{c}\text { Evaluation on goods } \\
\text { with local characteristic }\end{array}$ \\
\hline $\mathbf{X 2}$ & $\begin{array}{c}\text { Evaluation on } \\
\text { landscape features }\end{array}$ & X14 & $\begin{array}{c}\text { Evaluation on richness } \\
\text { of commodity types }\end{array}$ \\
\hline $\mathbf{X 3}$ & $\begin{array}{c}\text { Evaluation on } \\
\text { richness of landscape }\end{array}$ & X15 & $\begin{array}{l}\text { Evaluation on price of } \\
\text { tickets and recreation } \\
\text { activities }\end{array}$ \\
\hline $\mathrm{X} 4$ & $\begin{array}{c}\text { Evaluation on } \\
\text { landscape's value }\end{array}$ & $\mathrm{X16}$ & $\begin{array}{l}\text { Evaluation on price of } \\
\text { accommodation }\end{array}$ \\
\hline $\mathrm{X5}$ & $\begin{array}{c}\text { Evaluation on } \\
\text { ecological } \\
\text { environment }\end{array}$ & $\mathrm{X} 17$ & $\begin{array}{l}\text { Evaluation on price of } \\
\text { commodity }\end{array}$ \\
\hline X6 & Evaluation on & $\mathbf{X 1 8}$ & Evaluation on \\
\hline
\end{tabular}

\begin{tabular}{|c|c|c|c|}
\hline & $\begin{array}{c}\text { entirely appearance } \\
\text { of the city }\end{array}$ & & transportation service \\
\hline $\mathrm{X} 7$ & $\begin{array}{c}\text { Evaluation on } \\
\text { cleanness of the city }\end{array}$ & $\mathbf{X 1 9}$ & $\begin{array}{c}\begin{array}{c}\text { Evaluation on hotel } \\
\text { service }\end{array} \\
\end{array}$ \\
\hline X8 & $\begin{array}{c}\text { Evaluation on } \\
\text { catering features }\end{array}$ & $\mathbf{X 2 0}$ & $\begin{array}{c}\text { Evaluation on tourism } \\
\text { shopping service }\end{array}$ \\
\hline $\mathbf{X 9}$ & $\begin{array}{c}\text { Evaluation on } \\
\text { catering quality }\end{array}$ & $\mathbf{X 2 1}$ & $\begin{array}{c}\text { Evaluation on tour } \\
\text { guide service }\end{array}$ \\
\hline $\mathbf{X 1 0}$ & $\begin{array}{c}\text { Evaluation on traffic } \\
\text { convenience in and } \\
\text { around city }\end{array}$ & $\mathbf{X} 22$ & $\begin{array}{c}\text { Evaluation on public } \\
\text { security }\end{array}$ \\
\hline X11 & $\begin{array}{c}\text { Evaluation on } \\
\text { recreation features }\end{array}$ & $\mathbf{X 2 3}$ & $\begin{array}{c}\text { Evaluation on tourist } \\
\text { area capacity }\end{array}$ \\
\hline $\mathbf{X 1 2}$ & $\begin{array}{l}\text { Evaluation on } \\
\text { richness of } \\
\text { entertainment }\end{array}$ & X24 & $\begin{array}{l}\text { Evaluation on richness } \\
\text { of information provided } \\
\text { in sightseeing place }\end{array}$ \\
\hline
\end{tabular}

\section{B. Data Analysis Method}

After analysis the surveyed data, it is found that the correlation of the data is quite high, so its suitable for factor analysis. The statistical analysis showed that many indictors influence each other and a certain of correlation exist between the variables, so a considerable of information provided in this survey were overlapping. There are 24 evaluation indexes about the urban tourist's satisfaction involved in this paper, however, the average data about tourist's satisfaction reflected in many of the evaluation indexes indicate slightly differences, so it can't reflect the exiting problems of Chongqing urban tourism directly and clearly. The factor analysis can guarantee the least data information lost and at the same time by using the reducing dimension thought to find out the common factors. This method can not only simplified indicator structure but also made the analyzing process easy, intuitive and effective. This paper used SPSS19.0 statistical software to analysis the statistical data.

\section{1) Inspection of KMO and Bartlett}

The higher of KMO measure values (approximate 1.0) indicate the more common factors exist between the variables and more suitable for factor analysis. The KMO measure values in this study reach to 0.808 ,so it's suitable for factor analysis. Another question is whether the correlation matrix in the null hypothesis of Bartlett Test of Sphercity is identity matrix. It's not suitable for the factor analysis if it's turn out to be identity matrix. On the contrary, the lower of significant level(less than 0.05) the more suitable for the factor analysis, The P-value of Bartlett is 0.000 ,so it's suitable for factor analysis.

\section{2) Confirmation of Common Factors}

In the principal of eigenvalues (grater than 1)during the factor extraction to determine the number of common factors. From Table 2, there were four eigenvalues that greater than one, thus indicate that there are four common factors. The first four factors contained $79.908 \%$ information of evaluation indexes, which can be seen from cumulative variance proportion. Therefore, the original 24 indexes can be divided into four categories and made further analysis of samples. 


\begin{tabular}{|c|c|c|c|c|c|c|c|c|c|}
\hline \multicolumn{10}{|c|}{ Total Variance Explained } \\
\hline \multirow[b]{2}{*}{ Component } & \multicolumn{3}{|c|}{ Initial Eigenvalues } & \multicolumn{3}{|c|}{ Extract square and loaded } & \multicolumn{3}{|c|}{ Rotate square and loaded } \\
\hline & Total & Variance $\%$ & \begin{tabular}{|c|} 
Accumulation \\
$\%$
\end{tabular} & Total & $\begin{array}{c}\text { Variance } \\
\%\end{array}$ & Accumulation \% & Total & Variance $\%$ & Accumulation \% \\
\hline 1 & 6.586 & 27.443 & 27.443 & 6.586 & 27.443 & 27.443 & 5.713 & 23.803 & 23.803 \\
\hline 2 & 4.509 & 18.788 & 46.231 & 4.509 & 18.788 & 46.231 & 4.766 & 19.860 & 43.663 \\
\hline 3 & 4.226 & 17.610 & 63.840 & 4.226 & 17.610 & 63.840 & 4.520 & 18.832 & 62.495 \\
\hline 4 & 3.856 & $\mathbf{1 6 . 0 6 7}$ & 79.908 & 3.856 & 16.067 & 79.908 & 4.179 & 17.413 & 79.908 \\
\hline
\end{tabular}

Established the factor analysis model is not only find out the common factors but more important is to know the meaning of every common factor and analyze practical problems. However the meaning of the initial factors is ambiguous, and it's hard for solve practical problems so the factor rotation is needed. From Chart Three, it can be seen that the first common factor has a heavy load on the evaluation of public security, richness of entertainment, goods with local characteristic, tourism shopping service, recreation features, hotel service, richness of commodity types and the overall evaluation of urban tourism products, thus it can be called service factor one. The second common factor has a heavy load on evaluation of landscape features, richness of landscape, ecological environment, landscape's value, entirely appearance of the city and cleanness of the city, so it can be defined as landscape and environment factor. The third common factor has a heavy load on evaluation of accommodation price, catering quality, price of tickets and recreation activities, catering features and commodity price, so it can be defined as catering and price factor. The fourth common factor has a heavy load on the evaluation of transportation service, tour guide service, richness of information provided in sightseeing place, traffic convenience in and around city, tourist area capacity, so it defined as service factor two.

TABLE III. EXPLANATION OF COMMON FACTOR

\begin{tabular}{|c|c|c|c|c|}
\hline $\begin{array}{c}\text { Common } \\
\text { Factor }\end{array}$ & F1 & F2 & F3 & F4 \\
\hline Factors Names & $\begin{array}{c}\text { service } \\
\text { factor } \\
\text { one }\end{array}$ & $\begin{array}{c}\text { landscape } \\
\text { and } \\
\text { environment } \\
\text { factor }\end{array}$ & $\begin{array}{c}\text { caterin } \\
\text { g and } \\
\text { price } \\
\text { factor }\end{array}$ & $\begin{array}{c}\text { service } \\
\text { factor two }\end{array}$ \\
\hline Eigenvalue & $\mathbf{6 . 5 8 6}$ & $\mathbf{4 . 5 0 9}$ & $\mathbf{4 . 2 2 6}$ & $\mathbf{3 . 8 5 6}$ \\
\hline $\begin{array}{c}\text { Contribution } \\
\text { Rate }\end{array}$ & $\begin{array}{c}\mathbf{2 7 . 4 3 3} \\
\%\end{array}$ & $\mathbf{1 8 . 7 8 8 \%}$ & $\begin{array}{c}17.610 \\
\%\end{array}$ & $\mathbf{1 6 . 0 6 7 \%}$ \\
\hline $\begin{array}{c}\text { Relatively } \\
\text { Weight }\end{array}$ & $\mathbf{3 4 . 3 \%}$ & $\mathbf{2 3 . 5 \%}$ & $\mathbf{2 2 . 1 \%}$ & $\mathbf{2 0 . . 1 \%}$ \\
\hline
\end{tabular}

Based on the investigation of four common factors contribution rate, the relatively weight of service factor one, landscape and environment factor, catering and price factor and service factor two respectively is $34.3 \%, 23.5 \%$, $22.1 \%, 20.1 \%$, and they have different level of influence on tourist's satisfaction, among them, the service factor one and landscape and environment factor are the two most important factors that affect tourist's satisfaction. As shown in Table3.

TABLE IV. FACTOR SCORE COEFFICIENT MATRIX

\begin{tabular}{|c|c|c|c|c|}
\hline \multicolumn{5}{|c|}{ Component Score Coefficient Matrix } \\
\hline & \multicolumn{4}{|c|}{ Component } \\
\hline & 1 & 2 & 3 & 4 \\
\hline Overall evaluation on urban tourism products & .130 & .011 & .000 & -.025 \\
\hline Evaluation on landscape features & -.004 & .199 & -.024 & -.004 \\
\hline Evaluation on richness of landscape & -.018 & .190 & -.003 & .007 \\
\hline Evaluation on landscape's value & .001 & .182 & .006 & -.007 \\
\hline Evaluation on ecological environment & -.038 & .194 & -.020 & .002 \\
\hline Evaluation on entirely appearance of the city & -.011 & .183 & -.008 & -.007 \\
\hline Evaluation on cleanness of the city & -.007 & .181 & -.004 & .018 \\
\hline Evaluation on catering features & -.018 & -.022 & .214 & -.029 \\
\hline Evaluation on catering quality & -.010 & -.019 & .215 & -.005 \\
\hline Evaluation on traffic convenience in and around city & -.017 & .012 & -.001 & .224 \\
\hline Evaluation on recreation features & .154 & -.021 & -.014 & -.016 \\
\hline Evaluation on richness of entertainment & .157 & -.018 & -.018 & -.010 \\
\hline Evaluation on goods with local characteristic & .156 & -.017 & -.003 & -.009 \\
\hline Evaluation on richness of commodity types & .142 & .000 & -.008 & .016 \\
\hline Evaluation on price of tickets and recreation activities & -.004 & .010 & .208 & .007 \\
\hline Evaluation on price of accommodation & -.011 & -.014 & .219 & -.012 \\
\hline Evaluation on price of commodity & -.013 & .002 & .204 & .013 \\
\hline Evaluation on transportation service & -.005 & .002 & -.006 & .233 \\
\hline Evaluation on hotel service & .152 & -.033 & -.006 & -.023 \\
\hline Evaluation on tourism shopping service & .153 & -.005 & -.022 & .005 \\
\hline Evaluation on tour guide service & -.022 & .005 & -.006 & .228 \\
\hline Evaluation on public security & .155 & -.009 & -.009 & .002 \\
\hline Evaluation on tourist area capacity & .001 & -.012 & -.004 & .178 \\
\hline Evaluation on richness of information provided in sightseeing place & -.006 & .005 & -.011 & .225 \\
\hline
\end{tabular}




\section{FACTOR SCORE}

Used the regression method to calculate the coefficient of factor score functions, and accordingly write out the expression of factor score: from the factor score matrix in table4, the factor score expression can be obtained as follow:

$\mathrm{F} 1=0.13 \mathrm{X} 1-0.004 \mathrm{X} 2-0.018 \mathrm{X} 3+0.001 \mathrm{X} 4-$ $0.038 \times 5-0.011 \times 6-0.007 \times 7-0.018 \times 8-0.01 \times 9-$ $0.017 \times 10+0.154 \times 11+0.157 \times 12+0.156 \times 13+$ $0.142 \times 14-0.004 \times 15-0.011 \times 16-0.013 \times 17-$ $0.005 \times 18+0.152 \times 19+0.153 \times 20-0.022 \times 21+$ $0.155 \mathrm{X} 22+0.001 \mathrm{X} 23-0.006 \mathrm{X} 24$.

Similarly, the expressions of F2、F3 and F4 can be got. So the factor score value can be calculated, service factor one got about 77 points, the landscape and environment factor got about 76 points, the catering and price factor got about 74 points and service factor two got about 71 points.

Based on the contribution rate of each factor's weight,

The expression of composite score as follow:

$\mathrm{F}=(27.4 * \mathrm{~F} 1+18.8 * \mathrm{~F} 2+17.6 * \mathrm{~F} 3+16.06 * \mathrm{~F} 4) /$ 79.9. $=74.8$

\section{CONCLUSION}

The factor analysis results indicate that the extracted four main factors that influence tourist's satisfaction from high to low are: service factor one, landscape and environment factor, catering and price factor and service factor two. The contribution rate of service factor one and service factor two's the sum of variance can reached to $43.5 \%$, which is far much higher than the landscape and environment factor's variance contribution rate, so the service factor became the most important factor that influence on Chongqing urban tourism satisfaction.

The score of Chongqing urban tourism satisfaction is 74.8 , If treated more than 80 points as superior(evaluated as excellent, good and poor),Chongqing urban tourism satisfaction remained in the good range level, the degree of satisfaction needed to be further improved. From the main factor scores, the service factor one got the highest score, the landscape and environment factor, catering and price factor were in the middle, the service factor two got the lowest score, which suggested that tourist's satisfaction one service factor two is not high.

The main measure to improve urban tourism satisfaction is to improve Chongqing urban tourism service. The development of urban tourism not only relies on the landscape and environment, service is more important. Chongqing urban tourism got a lower score in transportation service, tour guide service, richness of information provided in sightseeing place, traffic convenience in and around city and tourist area capacity, thus the above aspects remain to be further improved.

\section{ACKNOWLEDGEMENT}

This research was supported by the Fund of key research project funding of Chongqing College of education (KY201138A).

\section{REFERENCE}

[1] The ranking list release of total income of tourism across the country in 2011 $[\mathrm{EB} / \mathrm{OL}]$ RenminNET,http://travel.people.com.cn/GB/16964715.html,201201-30.

[2] Dong Guanzhi, Yang Fengying, the study of evaluation system on urban tourist's satisfaction[J],Tourism Tribune, 2005 (1) 27-30.

[3] Nan Jianfei, My humble opinion on Fuzzy Comprehensive Evaluation of tourist' $\mathrm{s}$ satisfaction in tourism area [J],social scientist, 2008 (2) : 92-94.

[4] Guo Lingxia,Zhang Bo,Wang Yamin and so on, the study of tourist's satisfaction in tourism areas in Lanzhou[J], Economic Geography, 2010 (9) : 1580-1584.

[5] Jiao Shitai, the study of tourist' s satisfaction on red tourism areas and its influence factors $[\mathrm{J}]$, Journal of Northwest Normal University, 2012 (5) : 115-120.

[6] Huang Yanling,Huang Zhenfang,Yuan Linwang, The study of tourist's satisfaction on hotel evaluation model based on SEM[J],Tourism Tribune, 2006 (11) : 54-60.

[7] Huang Liuying, Chenlei, the study of influential factors of tourist's satisfaction in famous scenic spot[J],economic forum ,2010 (9) : 199-203.

[8] Chen Yuying, Empirical analysis of tourists perception and satisfaction in tourism destination[J],Journal of Henan University, 2006 (4) : 62-66.

[9] Li Ying, Analysis of tourist's satisfaction in tourism destination and its impact factors [J],Tourism Tribune, 2008 (4) : 43-48.

[10] Rui Tiansheng, Yan Hong, The analysis of tourist 's satisfaction on tourism product in Qinghai province and loyalty factors[J],Journal of Chongqing University , 2012 (3) : 14-18. 